\title{
HR Project Management
}

\author{
Viktoria Goroshenko ${ }^{1}$, Inna Kondaurova ${ }^{1},{ }^{*}$ Viktoria Zhilchenkova ${ }^{1}$, Olga Shtager ${ }^{1}$ \\ ${ }^{1}$ Donetsk National Technical University, Donetsk, Ukraine \\ "Email: inna.a.kondaurova@mail.ru
}

\begin{abstract}
The concept and essence of the project approach in management are described and the expediency of its application in HR management using the method of control questions. The essence of the method is to answer pre-defined questions, the results of which may lead to the conclusion of whether a project approach to HR management is being implemented at the enterprise and whether such implementation is appropriate. Using the method of indicators, the paper highlights characteristic features and conditions directly relevant to the organisation's activities and can simplify the use of the project approach or the approach to HR management itself. For the consistency of expert opinions on the feasibility of implementing a project approach and the correct choice of an action strategy, it is recommended to use the coefficient of variation indicator for the totality of expert assessments for each of the two evaluation scales.
\end{abstract}

Keywords: HR management, Project, Project management, Human resources, Assessment of management decisions, Expediency matrix of HR approach.

\section{INTRODUCTION}

In the past, the project approach with all the software necessary for it was mainly used by large construction or IT corporations since it was characterised by unique complexity, labour intensity and substantial investments of financial capital.

Recently, applying a project approach to human resource management in an organisation has become increasingly popular since every organisation has an HR specialist. This approach makes it possible, by purposefully combining resources, to achieve complex goals in a given time that require coordination of current activities, the involvement of many types of resources, a precise sequence of chronologically ordered actions.

This work aims to consider the features of project management of human resources and substantiate the feasibility of its application in current conditions.

\section{METHODOLOGY OF THE PROJECT APPROACH IN MANAGEMENT}

The project approach in management is universal and can be implemented, despite the direction of activity, duration and scale of the enterprise [1, p. 77].
At the same time, it is clear that the project approach to management is not a panacea and does not replace all other approaches used in the activities of enterprises (for example, program-target, program-resource and others).

According to the results of the annual global survey Pulse of the Profession - 2018, companies with a high level of maturity of project management are 2.5 times more likely to achieve their goals, $58 \%$ of organisations are fully aware of the value of project management, 93\% use standardised practices in project management [2].

And, nevertheless, many managers of modern enterprises and organisations have begun to consider $\mathrm{HR}$ project management as one of the factors that increase their leadership in the competition and realise the importance and necessity of the right approach to a unique resource - people, which, unlike technical innovations, cannot be copied by competitors and has unique qualities, properties and capabilities that contribute to achieving high performance [3, p. 141].

Clever use of project management tools makes it possible to form a comprehensive methodology for implementing the project approach, gradually implementing specific ways and means by which it can be solved. 
The peculiarity of the project approach in the organisation is its positive influence as strategic, organisational, economic, motivating and other efficiency factors [4].

Thus, the project approach is an effective tool that allows you to solve strategic problems in the face of constant changes. And, accordingly, the practical application of such an approach will have a positive impact on a more explicit definition of goals and objectives, optimisation of available human resources, more detailed control of the project implementation process and, as a result, will contribute to the growth of the effectiveness of business processes and ensure competitive advantages in the context of strategic changes.

\section{THE POSSIBILITIES OF APPLYING THE PROJECT APPROACH IN HR MANAGEMENT}

The basic unit on which the project approach is based is the concept of a project, which is sufficiently covered in modern works. At the same time, some authors emphasise that the project, first of all, is a specific action plan [5]; others believe that the concept of a project is more related to a system of goals and works [6], while others consider the concept of achieving a different result as the substantive basis of the project [7].

Since the term "project" (Latin "projectus") literally means "thrown forward", it means that any management object that can be represented as a separate large-scale, long-term project or several operational projects will assume the possibility of forecasting in the future.

Deciding on the use of the project approach in the organisation's activities requires a study of the appropriateness of its use, which is advisable to carry out using the method of control questions. The essence of the method is to answer pre-defined questions, the results of which may lead to the conclusion of whether a project approach to HR management is being implemented at the enterprise and whether such implementation is appropriate.

To provide an answer to the questions posed, we will form a matrix in which there are four quadrants following the combination of the actual existence of a project approach to HR management and the feasibility of its use (Fig. 1.).

At the same time, HR management should be considered as a field of knowledge and practical activity aimed at providing the organisation with high-quality personnel capable of performing the labour functions assigned to it and its optimal use through HR project management [8, p.375].

Following the established matrix, according to the study results of the actual use of the project approach, the following management decisions are possible (Table 1).

The study of the feasibility of implementing a project approach requires specifying the conditions under which it will be useful. To do this, you can use the method of indicators, that is, to identify characteristic features and formulate those conditions that are directly relevant to the organisation's activities and can simplify the use of the project approach or the approach to HR management itself.

According to the highlighted conditions, we will formulate several questions regarding the determination of the position of the enterprise organisation according to the proposed scale of expediency of applying a project approach to HR management (Table 2).

To answer these questions, it is most advisable to involve 5 specialists from the company since external experts may simply not have information about the specifics of the company's activities, the composition and qualifications of personnel, and the like. To ensure a sufficient level of simplicity of the study, it is proposed to recognise that such questions are equivalent.

Gradation of the assessment of the feasibility of implementing a project approach to the management of the company's activities:

0 - completely inappropriate

1 - has low expediency

\begin{tabular}{|c|c|c|}
\hline & \multicolumn{2}{|c|}{ The expediency of using the project approach } \\
\hline 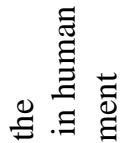 & $\begin{array}{l}\text { the project approach is used in the HR } \\
\text { management of the organisation, but its use } \\
\text { cannot be considered sufficiently appropriate }\end{array}$ & $\begin{array}{l}\text { the project approach is used in the HR } \\
\text { management of the organisation and its use is } \\
\text { appropriate }\end{array}$ \\
\hline 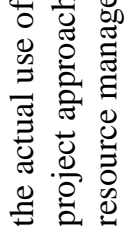 & $\begin{array}{l}\text { the project approach is not used in the HR } \\
\text { management of the organisation, but its use is } \\
\text { not appropriate }\end{array}$ & $\begin{array}{l}\text { the project approach is not used in the HR } \\
\text { management of the organisation, but its use is } \\
\text { entirely appropriate }\end{array}$ \\
\hline
\end{tabular}

Figure 1 Matrix of research on the feasibility of using a project approach to HR management. 
Table 1. Management decisions based on the formed matrix

\begin{tabular}{|l|l|}
\hline \multicolumn{1}{|c|}{ Formed combination } & \multicolumn{1}{c|}{ Management decisions } \\
\hline $\begin{array}{l}\text { the project approach is used in the HR management of } \\
\text { the organisation, but its use cannot be considered } \\
\text { sufficiently appropriate }\end{array}$ & $\begin{array}{l}\text { to ensure the use of other management approaches and } \\
\text { tools that would best match the characteristics of HR } \\
\text { management in the organisation }\end{array}$ \\
\hline $\begin{array}{l}\text { the project approach is used in the HR management of } \\
\text { the organisation, and its use is appropriate }\end{array}$ & $\begin{array}{l}\text { additional changes, in this case, are not necessary because } \\
\text { the management tools used to meet the management } \\
\text { features }\end{array}$ \\
\hline $\begin{array}{l}\text { the project approach is not used in the HR management } \\
\text { of the organisation, but its use is not appropriate }\end{array}$ & $\begin{array}{l}\text { regarding the approaches and management tools used, } \\
\text { additional research is required to determine to what extent } \\
\text { they correspond to the peculiarities of HR management in } \\
\text { the organisation. Additional measures to implement the } \\
\text { project approach, in this case, are not necessary }\end{array}$ \\
\hline $\begin{array}{l}\text { the project approach is not used in the HR management } \\
\text { of the organisation, but its use is entirely appropriate }\end{array}$ & $\begin{array}{l}\text { to ensure the organisation of the use of the project } \\
\text { approach under the identified features of HR management } \\
\text { in the organisation }\end{array}$ \\
\hline
\end{tabular}

2 - rather inappropriate

3 - rather expedient

4 - has high expediency

5 - fully expedient

The lower limit corresponded to the case when all experts gave the lowest possible assessment of importance, and the upper limit corresponded to the case when all experts gave the highest possible evaluation of importance.

Next, it is necessary to develop questions that allow us to determine whether there are complex tasks in the company's activities that are discrete and require considerable time in the conditions of involving many performers, or such tasks are initially of a project nature, or when they are performed, traditional tools of the project approach to managing the company's activities are used, and the like. Such questions are proposed in Table 3.

To ensure greater objectivity in assessing the feasibility of using a project approach in the company's activities, a set of experts from the company's employees in the number of 5 people also answers these

Table 2. Questions for assessing the feasibility of implementing a project approach to managing the company's activities

\begin{tabular}{|c|c|c|}
\hline Question & $\begin{array}{l}\text { Score in points of each } \\
\text { expert }\end{array}$ & $\begin{array}{l}\text { Average } \\
\text { with }\end{array}$ \\
\hline The company's activities are significantly diversified & & 2.8 \\
\hline At the enterprise, it is possible to distinguish independent unrelated tasks & & 1.4 \\
\hline The distribution of tasks and responsibilities of the staff is variable & & 1.4 \\
\hline $\begin{array}{l}\text { The company already uses information support in the context of individual } \\
\text { tasks }\end{array}$ & & 4.2 \\
\hline $\begin{array}{l}\text { As part of the staff, it is possible to distinguish independent relatively isolated } \\
\text { groups }\end{array}$ & & 2.6 \\
\hline The staff understands the specifics of project management & & 1.4 \\
\hline Management is interested in using project management & & 4.2 \\
\hline The staff can quickly adapt to the specifics of project management & & 2.6 \\
\hline Total: & & 20.6 \\
\hline
\end{tabular}


Table 3. Questions for evaluating the use of the project approach in the management of the company's activities

\begin{tabular}{|c|c|c|}
\hline Question & $\begin{array}{l}\text { Score in points of each } \\
\text { expert }\end{array}$ & $\begin{array}{l}\text { Average } \\
\text { with }\end{array}$ \\
\hline Setting the resource limit for each direction & & 4.6 \\
\hline $\begin{array}{l}\text { The non-cyclical nature of a significant majority of the tasks in which the } \\
\text { company participates }\end{array}$ & & 3.4 \\
\hline $\begin{array}{l}\text { Participation of the company in the implementation of technical- } \\
\text { economic tasks that are of a project nature }\end{array}$ & & 3 \\
\hline Instability of the tasks performed and their discreteness in time & & 1.6 \\
\hline Current use of traditional project approach tools in enterprise management & & 3.2 \\
\hline $\begin{array}{l}\text { Formal recognition of the use of the project approach in management in the } \\
\text { company's activities }\end{array}$ & & 2.36 \\
\hline $\begin{array}{l}\text { Approval of the responsibility of the company's employees for performing } \\
\text { complex tasks }\end{array}$ & & 1.6 \\
\hline $\begin{array}{l}\text { Building information support for managerial decision-making in the context } \\
\text { of individual tasks performed }\end{array}$ & & 3 \\
\hline Total: & & 23 \\
\hline
\end{tabular}

questions.

Gradation of the evaluation of the use of the project approach in the management of the enterprise:

0 - the project approach is not used

1 - little used

2 - rather not used

3 - rather used

4 - used in sufficient quantity

5 - the project approach is used everywhere

Thus, the lower limit corresponds to the case when all experts gave the lowest possible assessment of importance, and the upper limit corresponds to the case when all experts gave the highest possible evaluation of importance.

As for the previous list of questions, by definition, the equivalence of all questions is accepted; i.e., the maximum number of points for each question is 5 points.

Based on the results of answering the questions, it can be concluded that there are elements of a project approach in managing the company's activities.

At the same time, the initial assessment of the feasibility of using a project approach to managing the company's activities will be presented through the developed matrix as the arithmetic means of expert assessments on the two proposed scales according to formula 1 .

$c=\frac{1}{n} \sum_{i=1}^{n} c_{i}$, $c_{i}$ - individual expert assessment, $\mathrm{i}=1,2,3 \ldots$

$n$ - the serial number of the expert.

Having calculated the arithmetic mean for each attribute and summing up the points, we have an assessment of independent experts of 20.6 points for the expediency of using the project approach in the HR management of the organisation and 23 points for evaluating the use of the project approach in the enterprise.

\section{RESULTS DISCUSSION}

To confirm the consistency of experts' points of view regarding the feasibility of implementing a project approach to managing the company's activities, you can use the coefficient of variation indicator for the totality of expert assessments for each of the two evaluation scales.

Before conducting the survey, you can set a limit value of $\mathrm{n}$, which will indicate the consistency of expert assessments. Such a value can be 0.1-0.2. under conditions that will not exceed this value, a set of expert points of view regarding the feasibility of implementing a project approach to managing the company's activities can be considered consistent.

To find the coefficient of variation $\left(V_{j}\right)$ for each given quality ( $\mathrm{j}$ ), the following calculations must be performed: 
Table 4. Additional data for the calculation according to Table 2

\begin{tabular}{|c|c|c|c|c|}
\hline Expert & $\mathrm{Xi}$ & $\bar{X}$ & $\left\|X_{-}-\bar{X}\right\|$ & $\left\|X_{i}-\bar{X}\right\|^{2}$ \\
\hline 1 & 0 & 2.8 & 2.8 & 7.84 \\
\hline 2 & 3 & 2.8 & 0.2 & 0.04 \\
\hline 3 & 5 & 2.8 & 2.2 & 4.84 \\
\hline 4 & 2 & 2.8 & 0.8 & 0.64 \\
\hline 5 & 4 & 2.8 & 1.2 & 1.44 \\
\hline Total & & & & 14.8 \\
\hline
\end{tabular}

The variance of estimates given for a certain quality $\mathrm{j}$ determined by the formula (2).

$\mathrm{D}_{\mathrm{j}}=\frac{1}{\mathrm{~m}_{\mathrm{j}}-1} \sum_{\mathrm{i}=1}^{\mathrm{m}_{\mathrm{j}}}\left(\mathrm{C}_{\mathrm{ij}}-\mathrm{M}_{\mathrm{j}}\right)^{2}$

The standard deviation $\sigma_{\mathrm{j}}$ determined by the formula (3).

$\sigma_{\mathrm{j}}=\sqrt{\mathrm{D}_{\mathrm{j}}}$

The coefficient of variation of estimates $V_{j}$ determined by the formula (4).

$\mathrm{V}_{\mathrm{j}}=\frac{\sigma_{\mathrm{j}}}{\mathrm{M}_{\mathrm{j}}} * 100 \%$

Let's check the consistency of expert opinions for the example above, using the given formulas for the first sign of the feasibility of using the project approach in management for Table 2. To do this, we will calculate additional data (Table 4).

Let's apply formulas to get the results.

$\mathrm{D}_{\text {table } 3}=\frac{14,8}{5}=2,96$

$\sigma_{\text {table } 3}=\sqrt{2,96_{j}}=1,72$

$V_{j}=\frac{1,72}{2,8} * 100 \%=61,43 \%$

The average expert rating for the enterprise from the example for the ratings of 5 experts is 2.8 points with an average deviation from the average value, which is $61.43 \%$. Consequently, it can be concluded that the opinion of experts regarding the diversification of the company's activities (the first sign of the expediency of using the project approach at the enterprise) is not agreed.

Now let's check the consistency of experts' opinions on the first sign of the presence of project analysis. To do this, we will calculate additional data (Table 5).

Let's apply formulas to get the results.

$$
\begin{aligned}
& \mathrm{D}_{\text {table } 4}=\frac{1,2}{5}=0,24 \\
& \sigma_{\text {table } 4}=\sqrt{0,24}=0,49 \\
& \mathrm{~V}_{\mathrm{j}}=\frac{0,49}{4,6} * 100 \%=10,65 \%
\end{aligned}
$$

The average rating of experts for an enterprise for the ratings of 5 experts for the first feature is 4.6 points with an average deviation from the average value, which is $10.65 \%$. Consequently, it can be concluded that the opinion of experts regarding establishing a resource limit in each direction (the first sign of the feasibility of using a project approach in the enterprise) is agreed.

Therefore, in the enterprise taken as the basis of the example, the project approach is used and appropriate, but it is possible to improve the management level to get a better result.

The human potential is limitless; therefore, it is possible to consider improving the knowledge of the

Table 5. Additional data for the calculation according to Table 3

\begin{tabular}{|c|c|c|c|c|}
\hline Expert & $\mathrm{X}_{i}$ & $\bar{X}$ & $\mid X_{i}-\bar{X} \|$ & $\mid X_{i}-\bar{X} \|^{2}$ \\
\hline 1 & 5 & 4.6 & 0.4 & 0.16 \\
\hline 2 & 4 & 4.6 & 0.6 & 0.36 \\
\hline 3 & 5 & 4.6 & 0.4 & 0.16 \\
\hline 4 & 4 & 4.6 & 0.6 & 0.36 \\
\hline 5 & 5 & 4.6 & 0.4 & 0.16 \\
\hline Total & & & & 1.2 \\
\hline
\end{tabular}


enterprise's employees as a project to develop the potential of the enterprise.

That is why, for some companies, the education of their own, convenient personnel with the necessary knowledge is a production strategy [9].

At the same time, for team cohesion, it would be a much better move to train existing employees instead of attracting new employees from outside [10].

\section{CONCLUSIONS}

The project approach to human resource management will give a considerable advantage to enterprises, as they will develop their employees and invest in their training. It is also possible that the company invests money in the development of employees, but without a project approach, the budget is wasted instead of working for the company's benefit.

It is also worth paying special attention to the expected results from the project approach to personnel. First of all, the motivation of the staff increases. The employee has a desire to work better and more productively because he feels that the employer cares about him, namely, pays for his training.

\section{AUTHOR'S CONTRIBUTION}

The article attempts to substantiate the possibility of applying a project approach in HR management using the method of control questions.

\section{REFERENCES}

[1] Zh.R. Daukharin, L.V. Orlova, Project management as a tool for improving the efficiency of enterprises [Proektnyj menedzhment kak instrument povysheniya effektivnosti funkcionirovaniya predpriyatij] // Bulletin of the Samara Municipal Institute of Management [Vestnik Samarskogo municipal'nogo instituta upravleniya] 2 (2016) 75-80.

[2] Mark A. Langley, Success in Disruptive Times Expanding the Value Delivery Landscape to Address the High Cost of Low Performance Retrieved from the Internet address, 2018. Project Management Institute from: https://www.pmi.org

[3] V.V. Goroshchenko, Managerial innovations in HR activity [Upravlencheskie innovacii $\mathrm{v}$ sfere HRdeyatel'nosti] // Actual economics and management issues: theoretical and applied aspects [Aktual'nye voprosy ekonomiki i upravleniya: teoreticheskie i prikladnye aspekty]: IRT DONNTU [ADI DONNTU], Gorlovka 2 (2021) 140-145.
[4] G.A. Companeitseva, Project approach: concept, principles, efficiency factors [Proektnyj podhod: ponyatie, principy, faktory effektivnosti] // Scientific and methodological electronic journal "Concept" [Nauchno-metodicheskij elektronnyj zhurnal «Koncept»] 17 (2016) 363-368.

[5] O.B. Evreinov, A.B. Bardashevich, Development of a project approach to the organisation of the personnel training process of the enterprise [Razrabotka proektnogo podhoda $\mathrm{k}$ organizacii processa obucheniya personala predpriyatiya] // Scientific and Technical Bulletin of SPbPU. Economic Sciences [Nauchno-tekhnicheskie vedomosti SPbGPU. Ekonomicheskie nauki] 5 (2018) 142-149.

[6] T.N. Zhukova, Project management: (methodological aspect) [Proektnoe upravlenie: (metodologicheskij aspekt)], SPbSUE, 2011, 168 p.

[7] Ehsan Samimi, Jörg Sydow, Human resource management in project-based organisations: revisiting the permanence assumption, The International Journal of Human Resource Management 32(1) (2021) 49-83.

[8] V.V. Goroshchenko, HR project management is one of the conditions for the effective functioning of a modern organisation, Sustainable Development Strategy in Crisis Management of Economic systems [Upravlenie HR-proektami odno iz uslovij effektivnogo funkcionirovaniya sovremennoj organizacii, Strategiya ustojchivogo razvitiya $\mathrm{V}$ antikrizisnom upravlenii ekonomicheskimi sistemami]: DONNTU, Donetsk, 2021, pp. 374-380.

[9] G.W. Bohlander, S. Snell, Principles of Human Resource Management, Darden School of Business, 2013, 848 p.

[10] M.M. Romanova. Features of personnel management in the project organisation of activities [Osobennosti upravleniya personalom pri proektnoj organizacii deyatel'nosti] // Bulletin of Omsk University [Vestnik Omskogo universiteta] 2 (2011) 30-34. 